Mеталлофиз. новейшие технол. / Metallofiz. Noveishie Tekhnol. (c) 2017 ИМФ (Институт металлофизики 2017 , т. 39, № 8, cc. 1119-1128 / DOI: 10.15407/mfint.39.08.1119 им. Г. В. Курдюмова НАН Украины) Оттиски доступны непосредственно от издателя

Фотокопирование разрешено только

Напечатано в Украине.

в соответствии с лицензией

PACSnumbers: 62.20.Hg, 62.20.M-, 64.75.Op, 81.30.Mh, 81.40.Cd, 81.40.Lm, 81.40.Np

\title{
Metallographic and Mechanical Studies of a Cast Heat-Resisting Alloy
}

\author{
M. Aichaoui and A. Hadji \\ Foundry Laboratory, Department of Metallurgy and Materials Engineering, \\ Badji Mokhtar University, \\ 23000 Annaba, Algeria
}

\begin{abstract}
A heat-resistant steel tube from an ammonia plant made of modified HP40 steel that failed after short-term service is studied for damage mechanism. The assessment of material degradation is carried out using optical microscopy, scanning electron microscopy in combination with energy dispersive spectroscopy analysis, $x$-ray diffraction analysis, and mechanical tests. Results show that precipitation of the chromium-rich carbides induces the coalescence of grain boundaries. Significant growth and poor distribution of secondary carbides are also noticed through the matrix, which lead to a reduction of material ductility even after a short-term service. The main cause of failure appears to be damaged catalyst. Such a problem can cause a rise in temperature leading to localized overheating in the lower part of the tube. Overheating is primarily responsible for significant degradation in microstructure, creep strength, and mechanical properties of the tube.
\end{abstract}

Key words: heat-resistant steel, carbide, damage mechanism, overheating, creep.

Для встановлення механізму руйнування було вивчено виготовлену з модифікованої жароміцної сталі НР40 трубу з аміячного заводу, що вийшла з ладу після короткотермінового використання. Вивчення деградації матеріялу було проведено за допомогою оптичної та сканівної електронної мікроскопій у комбінації з енергодисперсійною спектроскопічною аналізою, рентгенодифракційними дослідженнями та механічними випробуваннями. Встановлено, що виділення насичених Хромом карбідів викликає коалесценцію меж зерен. Також встановлено істотне зростання та ро-

Corresponding author: Meriem Aichaoui

E-mail: meriem.aichaoui@gmail.com

Please cite this article as: M. Aichaoui and A. Hadji, Metallographic and Mechanical Studies of a Cast Heat-Resisting Alloy, Metallofiz. Noveishie Tekhnol., 39, No. 8: 11191128 (2017), DOI: 10.15407/mfint.39.08.1119. 
зріджений розподіл у матриці вторинних карбідів, що приводить до зниження пластичности матеріялу навіть після короткотермінового використання. Основною причиною виходу труб з ладу є пошкоджений каталізатор. Ця проблема може спричинити підвищення температури, що призводить до локального перегріву в нижній частині труби. Саме перегрівання, перш за все, є відповідальним за значні деградацію мікроструктури, погіршення межі плазучости та механічних властивостей труб.

Ключові слова: жароміцна сталь, карбід, механізм пошкодження, перегрів, плазучість.

Для установления механизма разрушения была изучена изготовленная из модифицированной жаропрочной стали НР40 труба с аммиачного завода, вышедшая из строя после кратковременного использования. Изучение деградации материала было проведено с помощью оптической и сканирующей электронной микроскопий в комбинации с энергодисперсионным спектроскопическим анализом, рентгенодифракционными исследованиями и механическими испытаниями. Установлено, что выделение насыщенных хромом карбидов вызывает коалесценцию границ зёрен. Также установлено существенное увеличение и разрежённое распределение вторичных карбидов в матрице, что приводит к снижению пластичности материала даже после кратковременного использования. Основной причиной выхода труб из строя является повреждённый катализатор. Эта проблема может вызвать повышение температуры, что приводит к локальному перегреву в нижней части трубы. Именно перегрев, в первую очередь, ответственен за существенные деградацию микроструктуры, ухудшение границы ползучести и механических свойств трубки.

Ключевые слова: жаропрочная сталь, карбид, механизм повреждения, перегрев, ползучесть.

(Received June 21,2017)

\section{INTRODUCTION}

Reformer furnaces are widely used in the petroleum and chemical industries [1]. Steam-methane reformers typically contain vertical tubes, which are expected to operate at about $900^{\circ} \mathrm{C}$ and $2 \mathrm{MPa}$. Tubes are packed with catalyst through which the reaction gases pass. The tube material is commonly centrifugally cast heat resistant steel. In addition to the high temperature and the internal pressure, the tube material must also be able to withstand high temperature corrosion from the chemical processes occurring within the tubes. The alloys commonly used are $\mathrm{Cr}-\mathrm{Ni}$ stainless steels. Formerly, a preferred composition was $25 \mathrm{Cr}, 20 \mathrm{Ni}$ and $0.4 \mathrm{C}$, designated as $\mathrm{HK}-40$ [2], but with increase in operating temperature many reformers started using the alloy $(\mathrm{Fe}-$ $\mathrm{Ni}-\mathrm{Cr}-\mathrm{Nb}$ ) for their good exhibition of creep strength, mechanical property and corrosion resistance at high temperatures. The micro- 
structure of these centrifugally cast microalloyed HP40-steel consists of austenite dendrites delineated by a network of eutectic carbides [3, 4]. In order to have long-time strength at high temperature, the austenitic $\mathrm{Cr}-\mathrm{Ni}$ matrix of these alloys is strengthened through a dispersion of hard deformation-resistant carbide particles. The high $\mathrm{Cr}$ content in this class of steels, lead to the precipitation of various types of chromium carbides, for example, precipitation of Cr-rich carbide $\mathrm{M}_{7} \mathrm{C}_{3}$ and $\mathrm{M}_{23} \mathrm{C}_{6}$ is very common. The addition of stabilizing elements such as $\mathrm{Nb}, \mathrm{Ti}$, and $\mathrm{V}$ usually results in MC type carbides [5, 6]. Under service conditions, precipitates initially formed in as-cast microstructures undergo morphological and chemical changes, which can be detrimental for the qualities listed above of the tube.

The reformer tubes were designed for $100000 \mathrm{~h}$ (11.4 years) of operation, but often some of the tubes in the furnace fail prematurely [7, 8]. Several reasons can affect the service life of the catalyst tubes. In general, overheating seems to be the more common failure mode leading to premature creep [7, 9-11]. The purpose of this paper is to investigate the material degradation through the characterization of microstructure and mechanical properties of the microalloyed $\mathrm{HP} 40 \mathrm{Nb}$ tube, which failed after 1 year of service in an ammonia plant.

\section{MATERIALS AND METHODS}

In order to evaluate the microstructure of the tube after exposure to service for about one year, metallographic specimens were cut from the tube and polished according to standard polishing procedures. Then sample surfaces were etched with an electrolytic solution of $10 \mathrm{~g}$ of oxalic acid in $100 \mathrm{ml}$ of water $(5 \mathrm{~V}, 10 \mathrm{~s})$.

The chemical analysis of the sample was carried out using x-ray fluorescence spectroscopy (XRF). The microstructure of the specimens was examined by using optical microscopy (OM), scanning electron microscopy (SEM) coupled with energy dispersive spectroscopy (EDS) and $\mathrm{x}$-ray diffraction (XRD).

The mechanical properties of the tube were evaluated by using tensile testing and Charpy impact testing at room temperature $\left(25^{\circ} \mathrm{C}\right) . \mathrm{Mi}$ crohardness testing was carried out, in order to identify the variation of the mechanical characteristics of the wall through the modification of the microstructure. The tests were performed along the tube thickness from the inner to the outer surface. The hardness was measured using a $200 \mathrm{~g}$ weight for $10 \mathrm{~s}$.

The specified chemical composition (in \% wt.) and the values analysed are presented in Table 1 . The chemical composition of the reformer tube material under investigation conforms to the chemical composition specification for the grade. The properties of the cast alloy are linked to the chemical composition, since it has an important 
influence on the formation of precipitates.

\section{RESULTS AND DISCUSSION}

\subsection{Visual Examination}

Figure 1 shows the damaged tube removed from the reformer furnace causing a shutdown of the furnace. Service exposed tube revealed normal appearance on both the inner and outer surfaces. There is no trace of cracks, carbon deposition or oxidation at a visual inspection. Even though localized plastic deformation were seen in the lower part of the tube. The content of the company report after failure shows that broken pieces of catalyst were seen. Such a damaged catalyst can cause a

TABLE 1. Chemical composition (in \% wt.) of the reformer tube alloy.

\begin{tabular}{c|c|c|c|c|c|c|c}
\hline Element & $\mathrm{C}$ & $\mathrm{Si}$ & $\mathrm{Mn}$ & $\mathrm{Cr}$ & $\mathrm{Ni}$ & $\mathrm{Nb}$ & $\mathrm{Ti}$ \\
\hline Specified & $0.40-0.50$ & $0.50-1.50$ & $\begin{array}{c}1.50 \\
(\max )\end{array}$ & $24-27$ & $33-36$ & $0.50-1.50$ & 0.30 \\
Analysed & 0.40 & 0.40 & 1.05 & 23.80 & 35.02 & 0.60 & 0.08 \\
\hline
\end{tabular}

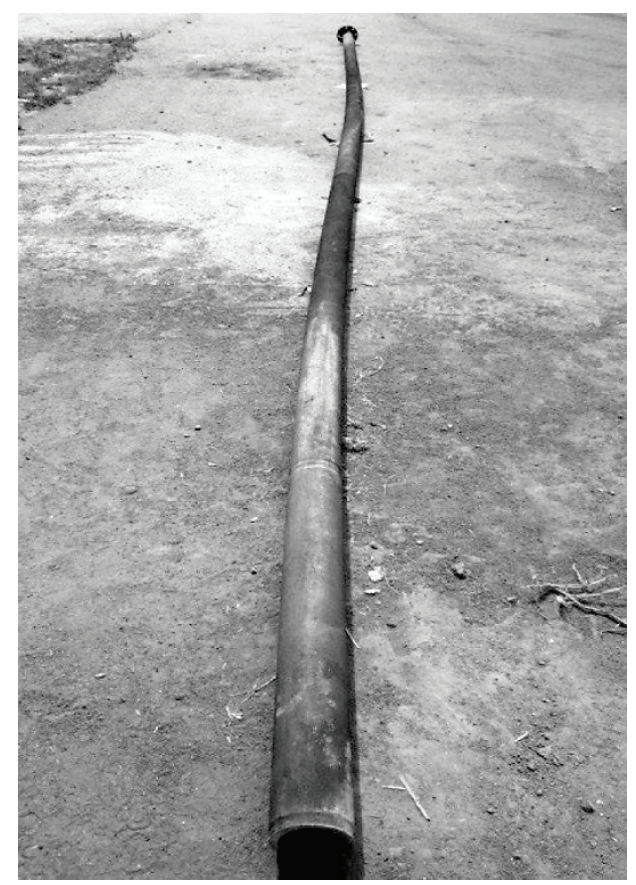

Fig. 1. Photography of the failed tube. 
rise in pressure and temperature by way of blocking the passage of the gas through the tube. Improper loading of the tubes with catalyst and extra shutdowns' cycles lead to the ineffectiveness of the catalyst.

\subsection{Metallographic Observations}

Microstructural examinations taken transversely to the tube axis focused on three regions, namely inner surface, midsection and outer surface. Figures 2, $a, b$ show the optical microstructure performed on the inner surface. It can be seen the interdendritic network of primary carbides, coarsened and forming a continuous network. Secondary carbides precipitate at the intradendritic regions during service exposure. Carbides particles are not uniformly distributed through the structure this can strongly affect the mechanical properties of the alloy. Creep voids in isolated form were seen in the inner wall. The creep voids are formed by the generation of missing atoms produced during diffusion of species under stress forming at last pores [12]. In the midsection of the tube (Fig. 2,c), the ageing due to high temperature service induced the formation of many isolated microvoids with a largest peanut shape formed by the coalescence of two or more voids leading to the progress of creep during service [13]. Figure $2, d$ shows the presence of string of cavities along the grain boundary, which link with increasing strain to

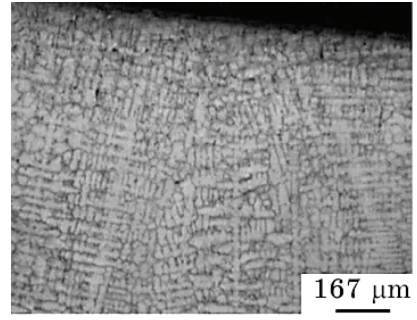

$a$

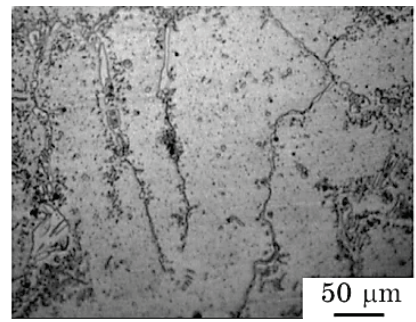

$b$

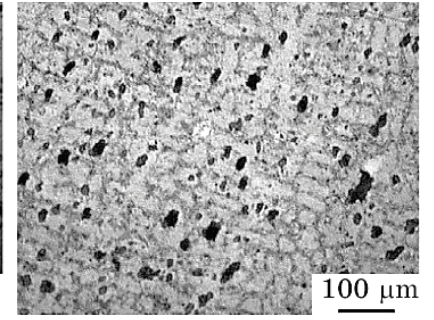

$c$

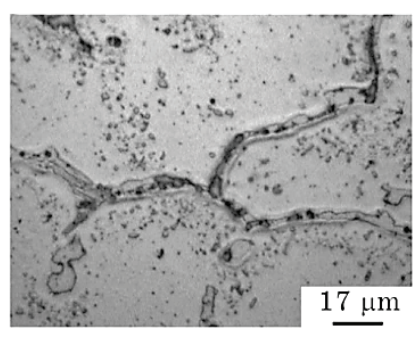

$d$

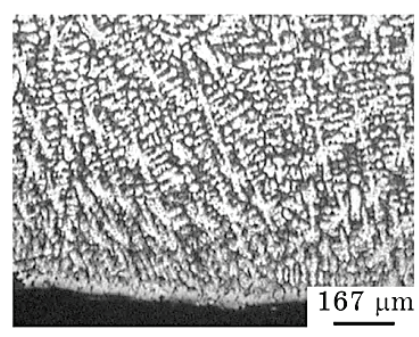

Fig. 2. Optical micrographs of transverse section of service exposed samples: inner wall $(a, b)$, middle cross section $(c, d)$, outer wall $(e)$. 
form microcracks. No creep voids were visible on the outer surface of the tube (Fig. 2,e).

The combination of thermal stresses and internal pressure stresses causes creep damage that typically develops at the inner surface of the tube and just below the inner surface. This is the reason as to why creep voids were absent from the outer surface. However, decarburization layers followed by internal oxidation were observed both in the outer and inner surfaces (Figs. 2, $e$ and 3,a). In the preservice condition, for the cast HP-microalloyed grade, microstructure is characterized by an austenitic matrix and a network of primary carbides [14].

Service conditions, particularly the effect of temperature and aging time, promote the dissolution of primary carbides and the development of a fine array of secondary carbides precipitated from the highly supersaturated matrix. It has been reported that these carbides are of two types: niobium carbide $(\mathrm{NbC})$ and chromium-rich carbides $\left(\mathrm{Cr}_{7} \mathrm{C}_{3}\right.$ or $\mathrm{Cr}_{23} \mathrm{C}_{6}$ ) [15-18]. Precipitates can be recognized by brightness contrast. The EDS microanalysis (Fig. 4, $a$ ) indicated that the white regions (Fig. 3, $b$ ) are niobium carbides in the form of $\mathrm{NbC}$ as confirmed by XRD (Fig. 5), while the dark phase at grain boundaries and also the dark small particles inside the grains (Fig. 3,c) are chromium riche. As revealed by the XRD results, these carbides are in the form of $\mathrm{Cr}_{7} \mathrm{C}_{3}$

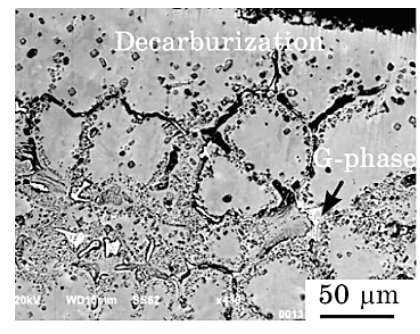

$a$

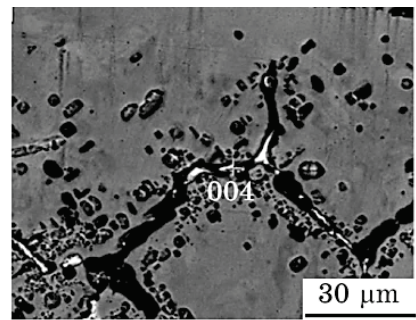

$b$

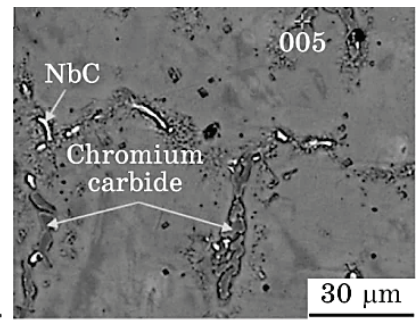

$c$
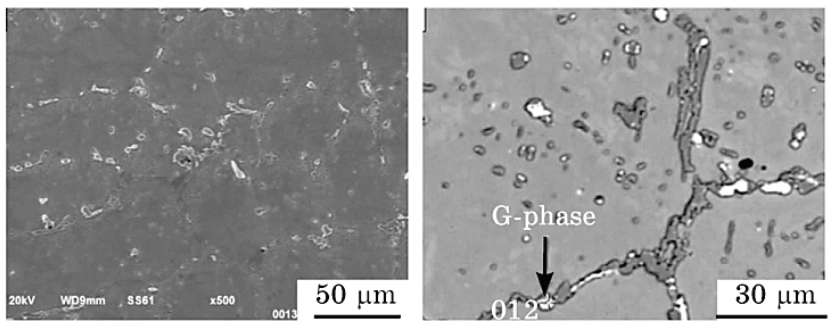

$d$

$e$

Fig. 3. SEM BSE and SEI micrographs of service exposed simples: inner wall $(a)$, higher magnification of Fig. $a(b)$, middle cross section with more blocky precipitation $(c, d)$, outer wall evidencing the G-phase $(e)$. 
and $\mathrm{Cr}_{23} \mathrm{C}_{6}$. Primary chromium carbides $\mathrm{Cr}_{7} \mathrm{C}_{3}$ are thus partially transformed into an intergranular and intragranular $\mathrm{M}_{23} \mathrm{C}_{6}$ precipitates, which are more stable at high temperature. The strength of carbides depends on their morphology, fine and uniform distribution through the matrix lead to a best combination of properties.

Nevertheless, continuous form of carbides will not be able to block dislocations motion and grain boundary sliding. In this case, plastic deformation of the tube occurs easier, creep will especially manifest in the lower part of the tube under the effect of its weight. Carbides in Figs. 3, $c, d$ are noticeably coalesced and blocky, which indicates overheating. Generally, precipitation and growth of carbides occurs for
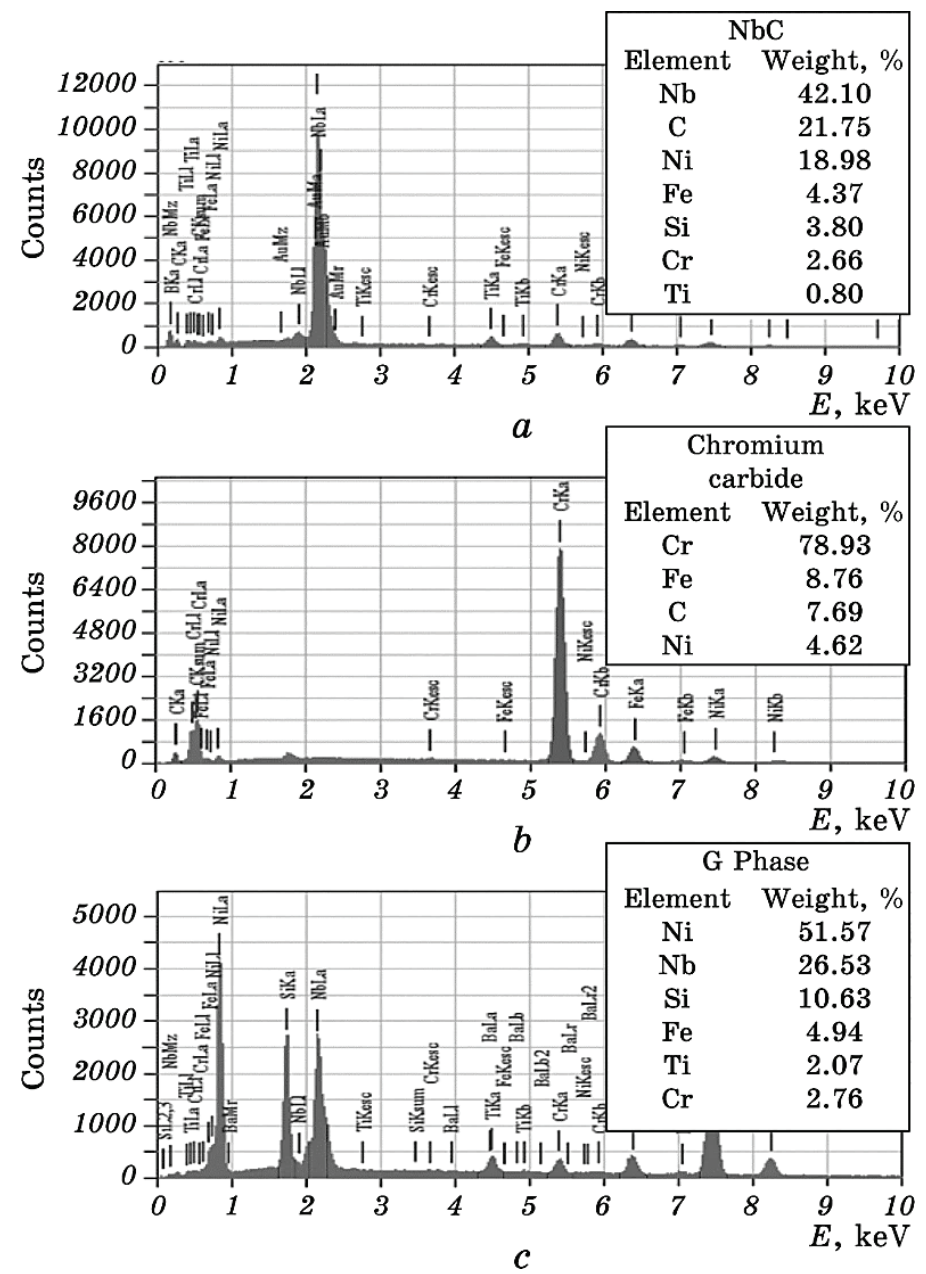

Fig. 4. SEM-EDS results of the precipitate phases marked with arrows in Figs. $3, a$ and $b$. 


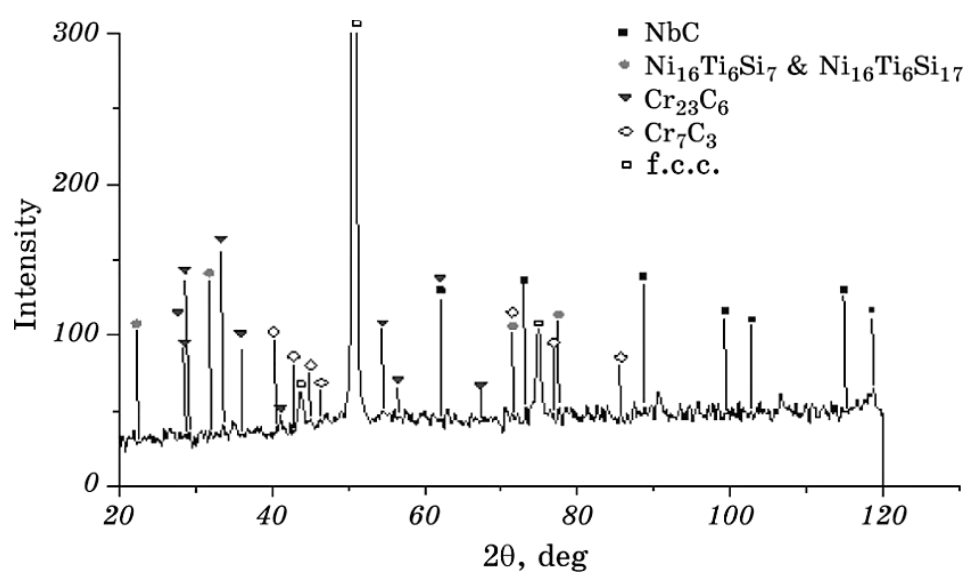

Fig. 5. XRD pattern of precipitate.

this kind of material exposed to high temperature.

However, this process needs a long time at normal service temperature. In the present study, it took only one year. This confirms that the failure is mainly due to localized creep deformation under overheating conditions. In Figure 3, light grey precipitates are observed and marked with arrows both at inner (Fig. 3,a) and at outer wall (Fig. 3, $e$ ). These precipitates are rich in $\mathrm{Ni}, \mathrm{Nb}$ and $\mathrm{Si}$ as shown by the EDS spectrum in Fig. 4, c. As quoted in literature [19, 20], Nb carbides are not stable at temperatures between 700 and $1000^{\circ} \mathrm{C}$, being transformed into nickel niobium silicides, identified as the G-phase. According to the results of the full area $x$-ray diffractions, there are four reflections on the diffraction pattern, which correspond to the G-phase.

\subsection{Mechanical Strength Properties}

Tensile and Charpy impact tests of the service-exposed tube were performed. Test results are shown in Table 2. Mechanical strength and ductility of the service exposed tube are decreased compared with the as cast tube. The fracture surface of the Charpy impact samples was analysed in order to identify the mode of fracture (Fig. 6).

TABLE 2. Mechanical properties of HP40-microalloyed.

\begin{tabular}{c|c|c|c|c}
\hline & $\begin{array}{c}\text { Tensile strength, } \\
\mathrm{MPa}\end{array}$ & $\begin{array}{c}\text { Yield strength, } \\
\mathrm{MPa}\end{array}$ & $\begin{array}{c}\text { Elongation, } \\
\%\end{array}$ & $\begin{array}{c}\text { Toughness, } \\
\mathrm{J}^{-3} \mathrm{~m}^{-3}\end{array}$ \\
\hline As cast & 515 & 295 & 12 & - \\
Aged & 445.15 & 330 & 7.41 & 6.5 \\
\hline
\end{tabular}




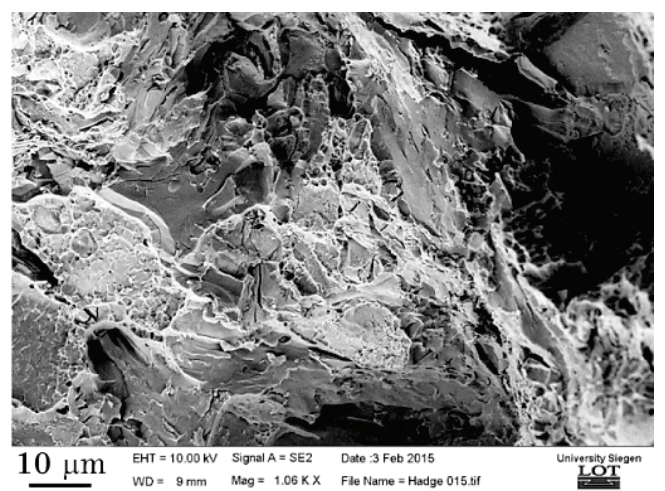

Fig. 6. Fractured surface.

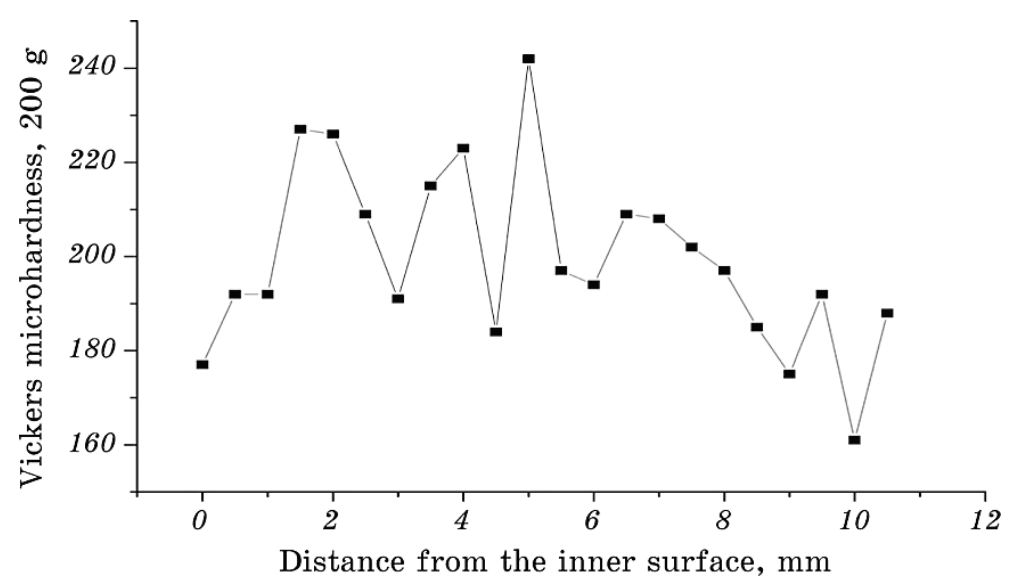

Fig. 7. Vickers microhardness profile measured across the wall thickness.

The image of the fractured surface reveals a mixed mode of fracture. Most of the surface is of the fragile type with a shiny fracture surface. Changes in the microstructure such as coalescence of carbides and presence of voids reduce the energy absorbed during fracture. Little plastic deformation is observed due to the formation of some dimples. Since matrix, metal around precipitates has good ductility.

The measured results of the microhardness profile are shown in Fig. 7. It can be seen that the evolution of microhardness values is heterogeneously following the heterogeneity of the microstructure (carbides hard and less hard matrix).

A slight reduction in the microhardness in the external face compared to the internal is found. This is due to the size difference of the grains between the two surfaces caused by the cooling rate during solidification process. 


\section{CONCLUSION}

The main cause of failure appears to be damaged catalyst. Such a problem could cause a rise in temperature leading to localized overheating in the lower part of the tube. This overheating lead to significant degradation in microstructure, creep strength and mechanical properties limiting the serviceability of the tube. Precautions should be taken while charging the catalyst to avoid such problems and to ensure the safe operation of the tubes.

\section{REFERENCES}

1. C. E. Jaske, The Annual Conference 'CORROSION 2005’ (April 3-7, 2005, Houston) (Houston: 2005), p. 05419.

2. Standard Specification for Castings, Austenitic, for Pressure-Containing Parts, No. A351/A351M-91.

3. X. Q. Wu, H. M. Jing, Y. G. Zheng, Z. M. Yao, W. Ke, and Z. Q. Hu, Mater. Sci. Eng. A, 293, Iss. 1-2: 252 (2000).

4. J. Rodriguez, S. Haro, A. Velasco, and R. Colas, Material Characterization, 45: 25 (2000).

5. T. Thorvaldsson and G. L. Dunlop, Metal Science, 16: 184 (1982).

6. G. D. Barbabela, L. H. de Almeida, T. L. da Silveira, and I. Le May, Material Characterization, 26: 193 (1991).

7. J. Swaminathan, K. Guguloth, M. Gunjan, P. Ray, and R. Ghosh, Engineering Failure Analysis, 15: 311 (2008).

8. L. Bonaccorsi, E. Guglielmino, R. Pino, C. Servetto, and A. Sili, Engineering Failure Analysis, 36: 65 (2014).

9. W. Z. Wang, F. Z. Xuan, Z. D. Wang, B. Wang, and C. J. Liu, Materials and Design, 32: 4010 (2011).

10. A. U. Hamid, H. M. Tawancy, A. I. Mohammed, and N. M. Abbas, Engineering Failure Analysis, 13: 1005 (2006).

11. K. Guan, H. Xu, and Zh. Wang, Engineering Failure Analysis, 12: 420 (2005).

12. T. L. da Silveira and I. Le May, Arabian Journal for Science and Engineering, 31, No. 2C: 99 (2006).

13. Azmi Abdul Wahab and K. V. Milo, Mater. Sci.Eng. A, 412, Iss. 1-2: 222 (2005).

14. G. D. A. Soares, L. H. de Almeida, T. L. da Selveira, and I. Le May. Material Characterization, 29: 387 (1992).

15. T. L. Shinoda, M. B. Zaghloul, Y. Kondo, and R. Tanaka, Transactions of the Iron and Steel Institute of Japan, 18: 139 (1998).

16. B. Piekarski, Material Characterization, 47: 181 (2001).

17. R. Dehmolaei, M. Shamanian, and A. Kermanpur, Material Characterization, 59: 1447 (2008).

18. S. Yu. Kondrat'ev, V.S. Kraposhin, G. P. Anastasiadi, and A. L. Talis, Acta Mater., 100: 275 (2015).

19. E. A. Kenik, P. J. Maziasz, R. W. Swindeman, J. Cervenka, and D. May, Scr. Mater., 49: 117 (2003).

20. D. J. Powell, R. Pilkington, and D. A. Miller, Acta Metall., 36, Iss. 3: 713 (1988). 